\title{
Congenital cutaneous candidiasis
}

\author{
Kai-Lung Chen, ${ }^{1}$ Mu-Ming Chien, ${ }^{2}$ Chien-Yi Chen, ${ }^{2}$ Hsien-Ching Chiu ${ }^{1}$
}

'Department of Dermatology, National Taiwan University Hospital, Taipei City, Taiwan ${ }^{2}$ Department of Pediatrics, National Taiwan University Children Hospital, Taipei City, Taiwan

\section{Correspondence to} Dr Hsien-Ching Chiu, hcchiu1003@ntu.edu.tw

Accepted 26 July 2016

\section{CrossMark}

To cite: Chen K-L, Chien M-M, Chen C-Y, et al. BMJ Case Rep Published online: [please include Day Month Year] doi:10.1136/ bcr-2016-216037

\section{DESCRIPTION}

A male neonate was born by caesarean section due to placental abruption at 34 weeks of gestation. Gestational diabetes and polyhydramnios were noted during pregnancy. There was no premature rupture of membrane. At birth, many thin erythematous finely scaly patches with satellite maculopapules were noticed on the neck, axillae, chest and lower abdomen (figure 1A). Respiratory distress developed shortly with tachypnoea and subcostal retraction. Potassium hydroxide preparations of the scaly patches revealed numerous budding spores and pseudohyphae. Parenteral fluconazole and topical sertaconazole were given at 1-day old, and within 48 hours respiratory and cutaneous manifestations promptly improved with resolution of erythema and surface desquamation (figure 1B). No systemic involvement of candidiasis was documented.

Congenital cutaneous candidiasis (CCC) was acquired in utero through vertical ascension of a maternal vaginal candidal infection, but the exact mechanism remains unknown. ${ }^{12}$ In contrast to the acquired cutaneous candidiasis (ACC), in which the lesions usually appear after first week of life and are mainly at the intertriginous areas, CCC often shows lesions at the non-flexural sites. The course
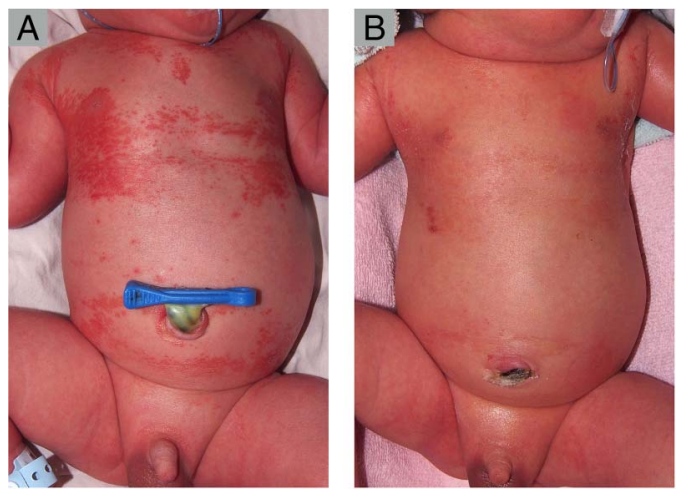

Figure 1 (A) Thin erythematous finely scaly patches with satellite maculopapules, mainly on the exposed areas. (B) Resolution of the erythema and surface desquamations were noticed within 48 hours of treatment with parenteral fluconazole and topical sertaconazole. is generally benign and self-limited, while premature infants and very low birthweight infants $(<1000 \mathrm{~g})$ are more likely to develop systemic disease. $^{3}$

The differential diagnosis includes ACC, impetigo, Listeria monocytogenes infection, erythema toxicum neonatorum, congenital syphilis, neonatal lupus erythematosus and Langerhans cell histiocytosis. ${ }^{3}$

Systemic antifungal therapy should be initiated in babies with respiratory distress or signs of sepsis, and also those with burn-like dermatitis or culture evidence of Candida spp from blood, urine or cerebrospinal fluid. ${ }^{23}$

\section{Learning points}

- Congenital cutaneous candidiasis usually appears at non-flexural sites on the first day, while acquired cutaneous candidiasis is mainly at the intertriginous areas after first week of life.

- The course of congenital cutaneous candidiasis is generally benign and self-limited, but systemic antifungal therapy should be initiated in babies with respiratory distress, sign of sepsis or culture evidence from any site.

Contributors K-LC wrote the first draft of the manuscript. M-MC, $\mathrm{C}-\mathrm{YC}$ and $\mathrm{H}-\mathrm{CC}$ revised the work critically for important intellectual content.

Competing interests None declared.

Patient consent Obtained.

Provenance and peer review Not commissioned; externally peer reviewed.

\section{REFERENCES}

1 Chen CJ, Weng YH, Su LH, et al. Molecular evidence of congenital candidiasis associated with maternal candidal vaginitis. Pediatr Infect Dis J 2006;25:655-6.

2 Aldana-Valenzuela C, Morales-Marquec M, Castellanos-Martínez J, et al. Congenital candidiasis: a rare and unpredictable disease. J Perinatol 2005;25:680-2.

3 Darmstadt GL, Dinulos JG, Miller Z. Congenital cutaneous candidiasis: clinical presentation, pathogenesis, and management guidelines. Pediatrics 2000;105:438-44. 
Copyright 2016 BMJ Publishing Group. All rights reserved. For permission to reuse any of this content visit http://group.bmj.com/group/rights-licensing/permissions.

BMJ Case Report Fellows may re-use this article for personal use and teaching without any further permission.

Become a Fellow of BMJ Case Reports today and you can:

- Submit as many cases as you like

- Enjoy fast sympathetic peer review and rapid publication of accepted articles

- Access all the published articles

- Re-use any of the published material for personal use and teaching without further permission

For information on Institutional Fellowships contact consortiasales@bmjgroup.com

Visit casereports.bmj.com for more articles like this and to become a Fellow 